\title{
Okul Öncesi Öğretmen Adaylarının ve Uygulama Öğretmenlerinin Öğretmenlik Uygulaması Dersine ilişkin Görüşlerinin İncelenmesi
}

\author{
Funda Eda TONGA', Feyza TANTEKIN ERDEN²
}

\begin{abstract}
Öz: Bu çalışmanın amacı okul öncesi öğretmen adaylarının ve uygulama öğretmenlerinin, Öğretmenlik Uygulaması dersine ilişkin görüşlerini incelemektir. Nitel araştırma desenlerinden olgu bilim çalışmasının kullanıldığı bu araştırmanın katılımcıları 41 okul öncesi öğretmen adayı ile 31 okul öncesi öğretmenidir. Açık uçlu görüş bildirim formu aracılığıyla toplanan veriler içerik analizi yöntemiyle analiz edilmiştir. Katılımcılara göre Öğretmenlik Uygulaması sürecinde karşılaşılan sorunlardan bazıları öğretmen adayı ile uygulama öğretmeni arasında yaşanan anlaşmazlıklar ya da sınıf yönetiminde yaşanan zorluklardır. Katılımcıların bu sorunlara yönelik çözüm önerilerine bakıldığında ise öğretmen adayı ve uygulama öğretmeninin sürekli iletişim içinde olması ya da sınıf yönetimini kolaylaştırmak adına ilgi çekici yöntemlerin kullanılması gibi önerilere yer verilmiştir. Kişilere düşen sorumluluklar kısmında ise uygulama öğretim elemanlarının da öğretmen adayları ve uygulama öğretmenleri kadar sürece dahil olması gerektiğine değinilmiştir. Bu bulgular doğrultusunda, araştırmanın öğretmen yetiştirme programlarında yer alan Öğretmenlik Uygulaması derslerinin geliştirilmesi ve iyileştirilmesinde destekleyici olacağı düşünülmektedir.
\end{abstract}

Anahtar Sözcükler: Okul Öncesi Öğretmenliği, Öğretmen Eğitimi, Öğretmenlik Uygulaması Dersi

\section{Investigating the Views of Pre-service and In-service Early Childhood Teachers Regarding Practice Teaching Course}

\begin{abstract}
This study intended to examine the views of pre-service and in-service early childhood teachers regarding Practice Teaching coursework. A phenomenological study utilizing qualitative research methods was conducted with 41 pre-service and 31 in-service early childhood teachers. Data collected through an open-ended feedback form was examined using content analysis. According to the participants, they faced some problems during the practice teaching process, such as disputes between pre-service and in-service teachers or difficulties in classroom management. Participants suggested some solutions for these problems, like ensuring communication between pre-service and in-service teachers and using interesting methods to facilitate classroom management. In the individual responsibilities section, it was mentioned that professors should be included in the process as much as pre-service and in-service teachers. In line with these findings, it is thought that the research will support the development and improvement Practice Teaching courses in teacher training programs.
\end{abstract}

Keywords: Early Childhood Education, Teacher Training, Practice Teaching Course

1 Orta Doğu Teknik Üniversitesi, Eğitim Fakültesi, Temel Eğitim Bölümü, Ankara, Türkiye, e-posta: edatonga@metu.edu.tr, ORCID: https://orcid.org/0000-0003-3350-9228

2 Orta Doğu Teknik Üniversitesi, Eğitim Fakültesi, Temel Eğitim Bölümü, Ankara, Türkiye, e-posta: tfeyza@metu.edu.tr, ORCID: https://orcid.org/0000-0001-6060-1877 
Eğitim sistemleri, öğrenci, öğretmen ve eğitim programı olmak üzere üç temel öğeden oluşmaktadır (Segall ve Wilson, 2004). Tüm öğeler önemli olmakla birlikte eğitimin niteliği, çoğunlukla programı uygulayan kişiler olan öğretmenlerin niteliğine dayanır (Kayange ve Msiska, 2016). Çocukların ilgi, ihtiyaç ve gelişim düzeylerine uygun eğitim sağlanması, ailelerin çocuklarının eğitimine katılması, toplumla iş birliği içinde olunması, yani eğitimde niteliğin arttırılması için öğretmenlerin nitelikli bir hizmet öncesi eğitime sahip olması gerekmektedir (Autry, Lee ve Fox, 2009; Saracho ve Spodek, 2007). Öğretmen adaylarının meslekleriyle ilgili bilgi ve becerileri elde etmelerini amaç edinen hizmet öncesi eğitim üç boyutta incelenebilir. Bu boyutlardan ilki; genel kültür bilgisi edindirmeyi amaçlayan genel eğitim boyutudur. İkinci boyut; öğretmenlik alanı ile ilgili bilgi ve becerileri kazandırmayı amaçlayan alan eğitimi boyutudur. Üçüncü boyut ise; öğretmenlik mesleğinin gerektirdiklerini uygulamalı olarak kazandırmayı amaçlayan meslek eğitimi boyutudur (Küçükahmet, 1976; akt. Severcan, 2007).

Öğretmenlik Uygulaması dersi, öğretmenlik lisans programları son sınıf öğrencilerinin güz ve bahar yarıyıllarında zorunlu olarak aldıkları, haftada iki saat teorik ders ve altı saat uygulama saatinden oluşan 5 kredilik bir derstir (Göktaş ve Şad, 2014; Şimşek, Alkan ve Erdem, 2013). Yükseköğretim Kurulu [YÖK] (1998) tarafından Öğretmenlik Uygulaması dersi; öğretmen adaylarının Eğitim Fakültelerinde teorik olarak aldıkları bilgi ve becerileri uygulama okullarında deneyimlemesi ve geliştirmesi olarak tanımlanmaktadır.

Eğitim Fakültelerinde verilen hizmet öncesi eğitimde Öğretmenlik Uygulaması dersleri öğretmen yetiştirmenin önemli unsurlarından biri olarak görülmektedir (Barnes, 2010). Çünkü Öğretmenlik Uygulaması dersleri son sınıfa gelen öğretmen adaylarının mesleğe başlamadan önce öğrendikleri bilgileri kullandıkları atölyelerdir (Akpınar, Çolak ve Yiğit, 2012; Becit, Kurt ve Kabakçı, 2009; Işıkoğlu, İvrendi ve Şahin, 2007; Paker, 2008; Wagler, 2007; Yalın Uçar, 2012). Öğretmen adayları bu dersler sayesinde gözlem yaparak, çocukları tanıyarak, plan hazırlayarak, gerektiğinde materyal geliştirerek ve çocukları değerlendirerek bireysel ve mesleki gelişimleriyle ilgili önemli adımlar atmış olurlar (Demir ve Çamlı, 2011; Dursun ve Kuzu, 2008; Özay Köse, 2015; Sarıçoban, 2008). Bu deneyimler aracılı̆̆ıyla öğretmen adayları nasıl bir öğretmen olacakları konusunda kendilerini gözlemleyip, olumlu ve olumsuz yönlerini fark etme fırsatı yakalarlar (Poulou, 2007). Buna ek olarak, Öğretmenlik Uygulaması dersleri ile öğretmen adaylarının mesleklerine yönelik tutumları belirlendiği için uygulama öğretmeni ile uygulama öğretim elemanının da rehberliğiyle mesleklerine yönelik uyumlarını arttırarak olumlu tutum geliştirmeleri hedeflenmektedir (Şimşek ve diğerleri, 2013).

Öğretmenlik Uygulaması dersleri ile ilgili alan yazın incelendiğinde yurtdışı ve yurtiçinde yapılan birçok çalışmaya rastlanmıştır. Uluslararası çalışmalarda, Öğretmenlik Uygulaması ile ilgili derslerin öğretmen eğitimi ve öğretmen adaylarının gelişimi üzerine olumlu etkilerinin vurgulandığı çalışmalar göze çarpmaktadır (Glatter, Castle, Cooper, Evans ve Woods, 2005; Pitfielda ve Morrison, 2009). Pitfielda ve Morrison tarafından 2009 yılında yapılan çalışmada, üniversite ve okul arasındaki işbirlikçi çalışmanın önemi üzerinde durulmuştur. Ulusal çalışmalarda ise Öğretmenlik Uygulaması derslerinin değerlendirilmesi, süreç boyunca karşılaşılan sorunların ve beklentilerin araştırılması ve süreçte etkin olan bireylerden özellikle de öğretmen adaylarından dersler ile ilgili görüş alınması en çok göze çarpan konulardandır (Baştürk, 2007; Boz ve Boz, 2006; Çetintaş ve Genç, 2005; Değirmençay ve Kasap, 2013; Eraslan, 2009; Güzel ve Cerit, 2006; Güzel ve Oral, 2006; Karasu Avcı ve Ünal İbret, 2016; Yıldız Altan, Ulutaş ve Demiriz, 2018). Karasu Avcı ve Ünal İbret tarafından 2016 yılında yapılan çalışmada, öğretmen adaylarının Öğretmenlik Uygulaması sürecinden beklentileri ve bu süreç sonunda karşılaştıkları problemler incelenmiştir. Öğretmen adayları tarafından Öğretmenlik Uygulaması dersinin öğretmenlik mesleğine hazırlaması ve öğretmenlerin öğretmen adaylarına destek sağlaması beklentiler olarak sunulurken uygulama öğretmenleri tarafından öğretmen olarak görülmeme ile çocuklar tarafından otorite sayılmama da karşılaşılan sorunlar arasında gösterilmiştir. Alan yazındaki çalışmalar sonucunda Öğretmenlik Uygulaması sürecinde karşılaşılan sorunlara ve zorluklara, dersin yararları ile ilgili bulgulara, dersin etkililiği ve niteliği hakkında önerilere ulaşılmaktadır (Akpınar ve diğerleri, 2012; Aslan ve Sağlam, 2018; Aytaçlı, 2012; Azar, 2003; Davran, 2006; Demir ve Çamlı, 2011; Gökçe ve Demirhan, 2005; Göktaş ve Şad, 2014; Özkılıç, Bilgin ve Kartal, 2008; Paker, 2008). Azar tarafından 2003 yılında yapılan çalışmada, Öğretmenlik Uygulaması sürecinin daha verimli ve etkili olabilmesi için 
paydaşların iş birliği içinde çalışmaları gerektiği vurgulanmıştır. Ayrıca çalışmaya katılan öğretmen adaylarının görüşlerine göre uygulama öğretim elemanlarının kendilerini yeterince gözlemlemediği ve değerlendirmediği sonucuna ulaşılmıştır. Benzer şekilde, Gökçe ve Demirhan tarafından 2005 yılında yapılan çalışmada da uygulama öğretim elemanlarının öğretmen adaylarını yeterince desteklemediği sonucuna ulaşılmıştır.

Alan yazında yer alan birçok çalışmanın katılımcıları öğretmen adaylarından oluşmaktadır (Karadüz, Eser, Şahin ve İlbay, 2009; Yıldırım, Özyılmaz Akamca, Ellez, Karabekmez ve Bulut Üner, 2019). Ancak, Öğretmenlik Uygulaması dersleri sadece öğretmen adaylarını kapsayan bir süreç değildir. Uygulama okullarındaki uygulama öğretmenleri ve eğitim fakültelerindeki uygulama öğretim elemanları da süreçte etkin rol oynar. Öğretmenlik Uygulaması sürecinin takibini yapmak kritik bir öneme sahiptir. Çünkü öğretmen adaylarının başarıya ulaşıp ulaşmadığını görmek, sürecin uygun bir şekilde yürütülüp yürütülmediğini kontrol etmek, süreçte ortaya çıkan sorunlara çözüm üretmek ve sürecin daha etkili hale getirilmesi için öneriler sunmak yapılan takip sayesinde gerçekleşir (Hergüner, Arslan ve Dündar, 2002). Genellikle bu takibi yapmakta görevli kişiler uygulama öğretim elemanlarıdır ve verdikleri dönütlerle öğretmen adaylarının gelişimlerine katkı sağladıkları gibi uygulama okulu ile üniversite arasında da köprü görevi üstlenerek iletişim kurarlar (Bates ve Burbank, 2008; Gökçe ve Demirhan, 2005). Ancak Öğretmenlik Uygulaması sürecinde birbirleri ile daha fazla zaman geçirerek etkileşim içinde olan, süreci en fazla etkileyen bireyler öğretmen adayları ve uygulama öğretmenleri olarak görülmektedir (Yıldız Altan ve diğerleri, 2018). $\mathrm{Bu}$ nedenle, bu çalışma okul öncesi öğretmen adaylarının ve uygulama öğretmenlerinin Öğretmenlik Uygulaması dersine ilişkin görüşlerini incelemek amacıyla gerçekleştirilmiştir. Bu amaç doğrultusunda aşağıdaki araştırma soruları oluşturulmuş ve onlara yanıt aranmıştır:

1. Okul öncesi öğretmen adaylarının Öğretmenlik Uygulaması dersine ilişkin görüşleri nelerdir?

1.a. Öğretmenlik Uygulaması dersinde karşılaşılan sorunlar ve bu sorunlara yönelik çözüm önerileri nelerdir?

1.b. Öğretmenlik Uygulaması dersinde kişilere düşen sorumluluklar ile ilgili katılımcıların görüşleri nelerdir?

2. Okul öncesi uygulama öğretmenlerinin Öğretmenlik Uygulaması dersine ilişkin görüşleri nelerdir?

2.a. Öğretmenlik Uygulaması dersinde karşılaşılan sorunlar ve bu sorunlara yönelik çözüm önerileri nelerdir?

2.b. Öğretmenlik Uygulaması dersinde kişilere düşen sorumluluklar ile ilgili katılımcıların görüşleri nelerdir?

\section{Yöntem}

\section{Araştırmanın Modeli}

Bu çalışmada, okul öncesi öğretmen adaylarının ve uygulama öğretmenlerinin Öğretmenlik Uygulaması dersine ilişkin görüşlerini incelemek için bir olgu bilim çalışması yürütmüşlerdir. Nitel araştırma; araştırmacıların görüşme formu, gözlem veya doküman analizi gibi farklı veri toplama araçları aracılığıyla veri topladığı, içinde bulunulan durumun tüm gerçekliği ve bütünüyle ele alındığı bir araştırma olarak tanımlanmaktadır (Yıldırım ve Şimşek, 2011).

\section{Katılımcilar}

Araştırmanın çalışma grubunu Ankara'da bulunan bir devlet üniversitesinin okul öncesi öğretmenliği bölümünde eğitim alan 41 son sınıf öğrencisi ile Ankara'da devlete bağlı okul öncesi eğitim kurumlarında çalışan 31 okul öncesi öğretmeni oluşturmaktadır. Çalışmanın katılımcıları kolay ulaşılabilir örneklem tekniği ile seçilmiştir. Çalışmaya katılan öğretmenler, öğretmen adaylarının Öğretmenlik Uygulaması dersi kapsamında uygulama yaptıkları okullarda görev yapan uygulama öğretmenleridir. Katılımcıların gerçek isimleri kullanılamayacağı için öğretmen adaylarına ÖA1'den ÖA41'e kadar, uygulama öğretmenlerine ise 
UÖ1'den UÖ31'e kadar takma isimler verilmiştir. Araştırmanın katılımcıları çalışma başlamadan konu ile ilgili bilgilendirilmiş ve gönüllülük durumları öğrenilmiştir. Tıpkı öğretmenlerde olduğu gibi öğretmen adayları da çalışmaya katılıp katılmamakta özgür olduklarının bilincinde olduklarından, sadece gönüllü olan katılımcılar ile çalışma sürdürülmüştür.

\section{Veri Toplama Aracı}

$\mathrm{Bu}$ araştırmanın verileri açık uçlu görüş bildirim formu aracıllı̆̆ıla elde edilmiştir. Araştırma soruları doğrultusunda alan yazın incelenerek oluşturulan açık uçlu sorular için iki alan uzmanından görüş alınmıştır. Uzman görüşüne ek olarak üç okul öncesi öğretmen adayı ve iki okul öncesi öğretmeni ile pilot çalışma yapılmıştır. Uzman görüşü ve pilot çalışma neticesinde soruları daha anlaşılabilir hale getirmek için üç soruda düzenleme uygun görülmüştür. Toplamda 11 sorudan oluşan açık uçlu görüş bildirim formu, Öğretmenlik Uygulaması dersinde karşılaşılabilecek sorunlar ve çözüm önerileri ile Öğretmenlik Uygulaması dersinde kişilere düşen sorumluluklar olmak üzere iki ana başlığa ayrılmıştır. Bu başlıklara ait örnek açık uçlu sorular Tablo 1'de verilmiştir. Çalışmanın katılımcıları olan öğretmen adaylarına ve uygulama öğretmenlerine herhangi bir yönlendirme olmaması açısından aynı sorular sorulmuştur.

Tablo 1

Örnek Açık Uçlu Sorular

\begin{tabular}{ll}
\hline Başlıklar & Örnek Sorular \\
\hline Sorunlar ve Çözüm Önerileri & • Etkinlik uygulama sırasında karşılaşılabilecek sorunlar neler olabilir? \\
& • Etkinlik uygulama sırasında karşılaşllabilecek sorunlara karşı çözüm önerileriniz nelerdir? \\
& • Etkinlik uygulandıktan sonra karşlaşıllabilecek sorunlar neler olabilir? \\
& • Etkinlik uygulandıktan sonra karşışıllabilecek sorunlara karşı çözüm önerileriniz nelerdir? \\
\hline Sorumluluklar & Öğretmenlik Uygulaması sürecinde öğretmen adaylarına düşen sorumluluklar nelerdir? \\
& • Öğretmenlik Uygulaması sürecinde uygulama öğretmenlerine düşen sorumluluklar nelerdir? \\
& • Öğretmenlik Uygulaması sürecinde uygulama öğretim elemanlarına düşen sorumluluklar \\
& nelerdir?
\end{tabular}

\section{Veri Toplanması ve Analizi}

Öğretmenlik Uygulaması sürecinde öğretmen adaylarının fakültede her hafta iki saat süren teorik derse katılmaları zorunludur. Bu ders eğitim fakültesi temel eğitim bölümünde görev yapan 5 öğretim elemanı üzerine kayıtlıdır ve aynı bölümde görev yapan 5 araştırma görevlisi süreç boyunca öğretim elemanlarına ve öğretmen adaylarına destek olmaktadır. Teorik dersi bütün sınıf yani 41 öğretmen adayı tek grup halinde aynı anda almaktadır. Bu ders hem çalışmanın yazarlarından olan hem de süreçte aktif olarak görev yapan bir araştırma görevlisi tarafından yürütülmektedir. Teorik dersin ilk haftasında öğretmen adaylarına yazılı olarak fikirleri sorulmuş ve en çok karşılaşılan fikirler ile dersin içeriği öğretmen adaylarının görüşlerine göre şekillenmiştir. Tablo 2' de her hafta değinilen konulara yer verilmiştir.

Tablo 2

Öğretmenlik Uygulaması Teorik Ders İ̧criği

\begin{tabular}{lll}
\hline \multicolumn{2}{l}{ Hafta } & İçerik \\
\hline 1. & Hafta & Öğretmen adaylarının ders içeriği ile ilgili görüşlerinin alınması \\
2. & Hafta & Etkinlik planı hazırlama (taslak ve etkinlik türü) \\
3. & Hafta & Etkinlik planı hazırlama (öğrenme süreci) \\
4. & Hafta & Etkinlik planı hazırlama (değerlendirme) \\
5. & Hafta & Etkinlik planı hazırlama (aile katılımı) \\
6. & Hafta & Etkinlik planı hazırlama (uyarlama) \\
7. & Hafta & Örnek etkinlik planı (müzik etkinliği) \\
8. & Hafta & Örnek etkinlik planı (drama etkinliği) \\
9. & Hafta & Örnek etkinlik planı (dış mekân) \\
10. & Hafta & Konuk (Özel Okul Yöneticisi) \\
11. & Hafta & Konuk (Özel Okul Yöneticisi) \\
12. & Hafta & Öğretmen adaylarının Öğretmenlik Uygulaması ile ilgili görüşlerinin alınması \\
\hline
\end{tabular}

Tabloda görüldüğü üzere öğretmen adayları ile etkinlik planı hazırlama konusunda çok fazla paylaşım yapılmıştır. Bu sayede, öğretmen adaylarının bu konudaki ihtiyaçlarına cevap verilmeye çalışılmıştır. Buna ek olarak, öğretmen adaylarının uygulama okullarında uygulayacakları etkinlikler uygulama öğretim elemanları 
tarafından önceden okunup gerekli düzenlemeler yapılmıştır. Öğretmen adayları haftada bir tam gün süresince uygulama yaptıkları okullarda bulunmuş ve süreç boyunca toplam 24 etkinlik planı hazırlamışlardır. Öğretmenlik Uygulaması devlete bağlı kurumlarda gerçekleştiğinden, birlikte çalışılan bütün okullarda sabahçı ve öğlenci olmak üzere ikili sistem uygulanmaktadır. Bu nedenle, öğretmen adayları genellikle sabah ve öğleden sonra olmak üzere iki grup için plan hazırlama, ortam düzenleme, uygulama ve değerlendirmeden sorumlu olmuştur. Öğretmenlik Uygulaması sürecinde uygulama öğretim elemanları uygulama okullarına giderek her öğretmen adayını en az dört etkinlik uygulama sürecinde gözlemlemiştir. Öğretmenlik Uygulaması sürecinin son haftasında öğretmen adaylarından ve uygulama öğretmenlerinden açık uçlu görüş bildirim formu aracılığıyla görüşleri alınmıştır.

Katılımcıların açık uçlu görüş bildirim formunda yer alan yazılı açıklamaları içerik analizi yöntemi aracılığıyla incelenmiştir (Yıldırım ve Şimşek, 2011). Analiz sürecinde yazılı olarak elde edilen veriler araştırmanın yazarlarından biri ile okul öncesi eğitimi alanında doktora yapan başka bir araştırmacı tarafından kodlanmıştır. Yapılan kodlamalar arasındaki tutarlılık Miles- Huberman $(\Delta=C \div(C+\partial) \times 100) \Delta$ : Güvenirlik katsayısı, C :Üzerinde görüş birliği sağlanan konu/terim sayısı, d: Üzerinde görüş birliği bulunmayan konu/terim sayısı) modeline göre hesaplanmış ve \%94 olarak bulunmuştur. Kullanılan modele göre kodlamaların güvenilir kabul edilmesi için kodlamalar arasındaki tutarlılığın \%80'den büyük olması gerekmektedir (Miles ve Huberman, 1994). İki araştırmacı kodlar üzerinde tartışarak ve açı uçlu görüş bildirim formundaki başlıkları kullanılarak kategorileri oluşturmuşlardır. Oluşturulan kategorilerin ve içerdikleri kodların daha anlaşılır sunulabilmesi için bulgular bölümünde tablolara yer verilmiştir. Ayrıca, gerek görülen yerlerde alıntılara yer verilerek bulgular desteklenmiştir.

\section{Veri Toplama Sürecinde İzlenen Etik İlkeler}

Veri toplama süreci gerçekleşmeden üniversitenin etik kurulundan 136 ODTU 2020 protokol numarası ile gerekli izin alınmış ve araştırmaya katılmaya gönüllü olan öğretmenler ve öğretmen adayları katılım onay formunu imzalamışlardır. Ayrıca katılımcılara paylaştıkları kişisel bilgilerin korunacağının ve katılımcıların görüşlerinin yalnızca bilimsel yayınlar için kullanılacağının güvencesi verilmiştir. Verilerin toplanması sırasında katılımcı gönüllülüğüne ve gizliliğine bağlı kalınmıştır.

\section{Bulgular}

Bu başlık altında açık uçlu görüş bildirim formu aracılığıyla elde edilen verilerin analizi sonucu ortaya çıkan bulgular sunulmuştur. Elde edilen bulgular, araştırma soruları dikkate alınarak oluşturulan alt başlıklar yardımıyla açıklanmıştır. Okuyucuya kolaylık sağlaması amacıyla kategoriler ve kodlar tablolar ile paylaşılmıştır.

\section{Öğretmenlik Uygulaması Sürecinde Karşılaşılan Sorunlar ve Çözüm Önerileri}

Açık uçlu görüşme formunda katılımcılara Öğretmenlik Uygulaması sürecinde karşılaştıkları sorunlar ve bu sorunlara yönelik çözüm önerileriyle ilgili sorular sorulmuştur. Tablo 3'te okul öncesi öğretmen adaylarının konuyla ilgili görüşlerine yer verilmiştir.

Tablo 3

Karşılaşılan Sorunlar ve Çözüm Önerileri (Öğretmen Adayı Bakış Açısı)

\begin{tabular}{|c|c|c|}
\hline Kategoriler & Kodlar & Kodlar \\
\hline & Sorunlar & Çözüm önerileri \\
\hline Etkinlik öncesinde & $\begin{array}{l}\text { Sınıf düzeninin uygun olmaması }(\mathrm{n}=27) \\
\text { Materyallere ulaşmada yaşanan maddi sıkıntılar } \\
(\mathrm{n}=13) \\
\text { Öğretmen ve öğretmen adayı arasında } \\
\text { anlaşmazlıkların yaşanması }(\mathrm{n}=11)\end{array}$ & $\begin{array}{l}\text { Sınıf düzeni etkinlikten önce sağlanmalı }(\mathrm{n}=13) \\
\text { Okul materyal desteği sağlamalı ve öğretmen adayı } \\
\text { kolay ulaşılabilir materyaller seçmeli }(\mathrm{n}=6) \\
\text { Sınıf öğretmeniyle iletişime geçip etkinlik planlaması } \\
\text { yapılmalı }(\mathrm{n}=28)\end{array}$ \\
\hline Etkinlik sırasında & $\begin{array}{l}\text { Sinıf yönetiminde zorluk çekme }(n=40) \\
\text { Öğretmenin müdahale etmesi }(n=37) \\
\text { Öğretmenin etkinliği izlememesi }(n=4)\end{array}$ & $\begin{array}{l}\text { İlgi çekici yöntemlerle sınıf yönetimi sağlanmalı }(\mathrm{n}=21) \\
\text { Sınıfın kontrolü tamamen aday öğretmene bırakılmalı } \\
(\mathrm{n}=23) \\
\text { Öğretmen etkinliği izlemeli ve gerektiğinde yardımcı } \\
\text { olmalı }(n=13)\end{array}$ \\
\hline
\end{tabular}




\begin{tabular}{lll}
\hline Etkinlik sonrasında & $\begin{array}{l}\text { Çocuklarla birlikte yapılan değerlendirmenin } \\
\text { uygun yapılmaması }(\mathrm{n}=35) \\
\text { Öğretmenlerden dönüt alamama }(\mathrm{n}=21)\end{array}$ & $\begin{array}{l}\text { Farklı değerlendirme yöntemleri ile tüm çocuklar } \\
\text { değerlendirilmeli }(\mathrm{n}=16) \\
\text { Öğretmenler, öğretmen adaylarını değerlendirmeli ve } \\
\text { dönüt vermeli }(\mathrm{n}=14)\end{array}$ \\
\hline Etkinlik dışında & $\begin{array}{l}\text { Öğretmen adayının sınıfta çocuklarla tek başına } \\
\text { bırakılması (n=19) }\end{array}$ & $\begin{array}{l}\text { Uygulama öğretim elemanları okul yetkilileri ile } \\
\text { görüsüüp öğretmen adaylarının sorumluluklarını } \\
\text { belirlemeli (n=18) }\end{array}$ \\
& $\begin{array}{l}\text { Öğretmen adaylarının temel ihtiyaçlarının } \\
\text { karşılanmaması }(\mathrm{n}=15)\end{array}$ & \\
\hline
\end{tabular}

Tablo 3'te görüldüğü üzere öğretmen adaylarının açık uçlu görüşme formundaki Öğretmenlik Uygulaması sürecinde karşılaştıkları sorunlar ve bu sorunlara yönelik çözüm önerileri ile ilgili sorulara verdikleri cevaplar etkinlik öncesinde, etkinlik sırasında, etkinlik sonrasında ve etkinlik dışında olmak üzere dört kategoriye ayrılmışır.

Etkinlik öncesinde öğretmen adaylarının en çok karşılaştıkları sorunlardan bazıları sınıf düzeninin uygulayacakları etkinliklere uygun olmaması ve sınıfın öğretmeni ile anlaşmazlıkların yaşanmasıdır. Katılımcılar, sınıfların küçük olması ya da mobilyalarla dolu olması gibi nedenlerden dolayı hareketli etkinlikler hazırlayamadıklarını ve uygulama öğretmenlerinin de etkinlik öncesinde düşüncelerini belirtmedikleri için sonrasında memnuniyetsizlik yaşadıklarını belirtmişlerdir. Öğretmen adaylarının bu sorunlara karşı çözüm önerisi; sınıfın öğretmeni ile etkinlik öncesinde iletişim halinde olarak sınıf düzeninin etkinliğe başlamadan sağlanmasıdır. Katılımcıların verdiği cevaplara ilişkin örnek aşağıda sunulmuştur:

Etkinlikler konusunda uygulama öğretmenimle ortak paydada buluşamadık. Kendisi etkinliklerimi yazmadan ona danıştığımda fikrini belirtmemesine rağmen etkinlik sonunda yaptığım şeylerden hiç memnun olmadı. Sanırım o daha çok ürün odaklı etkinlikler istiyordu. Etkinlik bitince mutlaka bir şey çıssın istiyordu. Benimkiler süreç odaklı olduğu için beğenmemiş olabilir (ÖA4).

Yukarıda verilen örnekteki katılımcı ile aynı fikirde olan bir başka öğretmen adayının cevabı aşağıda örnek olarak sunulmuştur:

Staj boyunca ne yaparsam yapayım sınıf öğretmenim etkinliklerimi beğenmedi. Sene sonu yapacakları sergiye ürün istediği için benim etkinliklerim onun beklentilerini karşılamadı. Bence böyle sorunlar yaşanmaması için etkinlikler bir hafta önceden öğretmenle konuşulmalı ve üniversitedeki hocalarımız gibi öğretmen de bize dönüt vermeli (ÖA16).

Öğretmen adaylarının etkinlik öncesinde karşılaştıkları bir diğer sorun ise etkinliklerde kullanacakları materyallere ulaşırken yaşadıkları maddi sıkıntılardır. Bu soruna yönelik sunulan çözüm önerileri ise öğretmen adaylarının atık materyaller gibi kolay ulaşılabilir materyalleri kullanmaları ve staj okulunun materyal sağlama konusunda öğretmen adayına destek olmasıdır. Konuyla alakalı bir katılımcının fikri aşağıda sunulmuştur:

Materyal hazırlamak maliyetli bir süreç olduğu için maddi olarak beni çok zorluyor. Hazır materyaller almak için de para gerekiyor. Bazen okul, sınıfta bulunan hiçbir materyali kullanmamıza izin vermiyor. O kadar zorlanıyorum ki artık etkinliğe göre materyal almak yerine elimdeki materyallere göre etkinlik yazmaya başladım (ÖA24).

Etkinlik sırasında öğretmen adaylarının karşılaştıkları sorunlardan biri sınıf yönetimi ile ilgilidir. Katılımcılar sınıf yönetimini sağlama konusunda zorluk yaşadıklarını belirtirken, çözüm önerisi olarak da parmak oyunu, tekerleme ya da şarkılar gibi ilgi çekici yöntemlerin kullanılabileceğini ifade etmişlerdir. Buna ek olarak, öğretmen adaylarının etkinlik sırasında uygulama öğretmenlerinden dolayı karşılaştıkları sorunlar da bulunmaktadır. Bu sorunlar, uygulama öğretmenlerinin etkinliğe çok fazla müdahale etmesi ya da etkinlik sırasında sınıfta bulunmamasıdır. Öğretmen adaylarının bu konudaki çözüm önerisi ise etkinlik sırasında sınıf yönetiminin tamamen kendilerine bırakılması ve uygulama öğretmeninin etkinliği izlerken sadece gerekli yerlerde öğretmen adayına yardım etmesidir. Bu konuda katılımcların verdiği cevaplara ilişkin örnek aşağıda sunulmuştur:

Ben etkinliğimi uygularken sınıfın öğretmeni sürekli çocuklara ya da bana müdahale ediyor. Bu yüzden çocuklar beni öğretmenleri gibi görmüyor. Mesela etkinlik sürecinde bir soruları olduğunda bana değil de öğretmenlerine soruyorlar. Öğretmenleri olarak görmedikleri birinin de sözünü dinlemedikleri için sınıfı yönetirken çok zorlanıyorum (ÖA18).

Aşağıda verilen örnek, bir diğer öğretmen adayının da aynı görüşü paylaşttğını göstermektedir:

Etkinlik sürecinde o kadar rahatsız hissediyorum ki artık ne desem öğretmen bir şey diyecek diye çekinir hale geldim. 
Oturma düzeninden tutun da kitap okuma şeklime ya da etkinlik sonunda sorduğum sorulara kadar her şeye etkinlik devam ederken dahil oluyor. Bu konuda gerçekten çok zorlandım. Keşke sadece etkinliği izleseydi ve sınıf yönetimini bana biraksaydı (ÖA37).

Öğretmen adaylarının etkinlik sonrasında karşılaştıkları sorunlardan biri etkinlik süreciyle ilgili çocuklarla birlikte yapılan değerlendirmenin uygun şekilde yapılamamasıdır. Katılımcılar etkinlik bittiğinde değerlendirmeye süre kalmadığını ve uygun zamanı bulsalar bile çocukların dikkat sürelerinin değerlendirme yapmak için yeterli olmadığını belirtmişlerdir. Bu soruna yönelik, farklı değerlendirme yöntemleri kullanarak bütün çocukların değerlendirilmesini de çözüm önerisi olarak sunmuşlardır. Konuyla alakalı bir katılımcının cevabı aşağıda sunulmuştur:

Değerlendirmeye geçtiğimizde çocukların sabrı ve dikkati kalmıyor ve değerlendirme kısmını verimli geçiremiyorum. Sorduğum sorulara genelde belli çocuklar cevap veriyor ve diğerleri için sıkıcı bir süreç oluyor. Etkinlik konusuyla alakalı poster hazırlığı ya da çalışma sayfası gibi yöntemlerle değerlendirme yapılırsa daha verimli olabilir (ÖA32).

Etkinlik sonrasında karşılaşılan bir diğer problem ise uygulama öğretmenlerinden dönüt alamamayla ilgilidir. Öğretmen adayları bu soruna yönelik uygulama öğretmenlerinin, öğretmen adaylarını değerlendirmesini ve dönüt vermeleri gerektiğini savunmuşlardır. Bu sayede etkinliklerini daha iyi hale getirebileceklerini ve kendilerini geleceğin öğretmenleri olarak geliştirebileceklerini ifade etmişlerdir.

Etkinlik dışında öğretmen adaylarının en çok karşılaştıkları sorunlardan biri sınıfta çocuklarla tek başına bırakılmaktır. Bir diğer sorun ise öğretmen adaylarının yemek ya da mola gibi temel ihtiyaçlarının karşılanmamasıdır. Bu iki sorunla alakalı olarak öğretmen adaylarının sunduğu çözüm önerisi ise uygulama öğretim elemanlarının Öğretmenlik Uygulaması sürecinin en başında okul yetkilileri ile görüşüp öğretmen adayının sorumlulukları ile karşılıklı beklentileri detaylıca konuşmalarıdır. Katılımcıların verdiği cevaplara ilişkin örnek aşağıda sunulmuştur:

Öğle arasında mola vermeye fırsatımız olmuyor. Sabah sorumlu olduğumuz sınıftaki çocuklar giderken öğleden sonra sorumlu olduğumuz sinıftaki çocuklar geliyor ve onlarla ilgilenmemiz bekleniyor. Dinlenemediğimiz için öğleden sonraları sadece etkinlik uygulama anlamında değil bütünüyle verimsiz geçiyor. Çok yorgun oluyorum ve uygulama yapma konusunda motivasyonum düşüyor (ÖA2).

Tablo 4'te uygulama öğretmenlerinin konuyla ilgili görüşlerine yer verilmiştir.

Tablo 4

Karşılaşılan Sorunlar ve Çözüm Önerileri (Uygulama Öğretmeni Bakış Açısı)

\begin{tabular}{|c|c|c|}
\hline Kategoriler & Kodlar & Kodlar \\
\hline & Sorunlar & Çözüm önerileri \\
\hline Etkinlik öncesinde & $\begin{array}{l}\text { Etkinlik hazırlığı için sınıfın uygun hale } \\
\text { getirilmemesi }(\mathrm{n}=24) \\
\text { Çocukların ilgi, ihtiyaç ve gelişim özelliklerini göz } \\
\text { önüne almadan etkinliklerin hazırlanması }(\mathrm{n}=20) \\
\text { Aylık ya da günlük plan ile uyumsuzluk }(\mathrm{n}=8)\end{array}$ & $\begin{array}{l}\text { Sınıf düzeni etkinlikten önce sağlanmalı }(\mathrm{n}=15) \\
\text { Sınıf öğretmeniyle iletişime geçip etkinlik planlaması } \\
\text { yapılmalı }(\mathrm{n}=17)\end{array}$ \\
\hline Etkinlik sırasında & Sınıf yönetiminde zorluk çekme $(\mathrm{n}=30)$ & İlgi çekici yöntemlerle sınıf yönetimi sağlanmalı (n=19) \\
\hline Etkinlik sonrasında & $\begin{array}{l}\text { Değerlendirmenin uygun yapılmaması }(n=25) \\
\text { Her çocuğa eşit davranılmaması }(n=10)\end{array}$ & $\begin{array}{l}\text { Farklı değerlendirme yöntemleri ile tüm çocuklar } \\
\text { değerlendirilmeli }(n=26)\end{array}$ \\
\hline Etkinlik dışında & $\begin{array}{l}\text { Öğretmen adaylarının etkinlik dışında çocuklarla } \\
\text { ilgilenmemesi }(\mathrm{n}=29)\end{array}$ & $\begin{array}{l}\text { Öğretmen adayı çocuklarla iletişim halinde olmalı }(n=14) \\
\text { Çocuklar her zaman gözlemlenmeli }(n=18)\end{array}$ \\
\hline
\end{tabular}

Tablo 4'te görüldüğü üzere uygulama öğretmenlerinin açık uçlu görüşme formundaki Öğretmenlik Uygulaması sürecinde karşılaştıkları sorunlar ve bu sorunlara yönelik çözüm önerileri ile ilgili sorulara verdikleri cevaplar etkinlik öncesinde, etkinlik sırasında, etkinlik sonrasında ve etkinlik dışında olmak üzere dört kategoriye ayrılmıştır.

Etkinlik öncesinde uygulama öğretmenlerinin karşılaştıkları sorunların başında etkinlik için sınıfın uygun hale getirilmemesi gelmektedir. Buna çözüm olarak da sınıf düzeninin etkinliğe başlamadan önce öğretmen adayı tarafından sağlanması önerilmiştir. Konuyla ilgili bir katılımcının görüşü aşağıda örnek olarak sunulmuştur:

Öğretmen adayları sınıfın değiştirilemez olduğunu düşünüyorlar sanırım. Çünkü asla yeni bir köşe oluşturmaya yeltenmiyorlar. Etkinlik öncesinde sinıfa uygun materyaller mutlaka getirilmeli. Mesela sebzeler- meyveler konusu 
işleniyorsa öğretmen adayı sınıfın bir bölümünü manav gibi düzenlemeli. Sebze- meyve oyuncakları, manav önlüğü, oyuncak para, tartı gibi materyallerle etkinlik desteklenmeli (UÖ13).

Uygulama öğretmenlerinin belirttiği diğer sorunlar ise etkinliklerin çocukların ilgi, ihtiyaç ve gelişim özelliklerini göz önüne almadan hazırlandığı ile halihazırda kullanılmakta olan aylık ve günlük plana uyulmamasıdır. Bu sorunlara çözüm olarak da öğretmen adaylarının etkinliklerini planlamadan önce uygulama öğretmenleriyle iletişim içinde olmaları önerilmiştir. Çalışmaya katılan uygulama öğretmenlerinden biri bu konudaki görüşlerini aşağıdaki sözlerle dile getirmiştir:

Bazen öyle zamanlar oluyor ki sınıfta uygulanan etkinliğin bizim takip ettiğimiz aylık planla hiçbir alakası olmuyor. Böyle olunca çocukların gelişim özelliklerine uygun etkinlik tanımından da uzaklaşılıyor. Öğretmen adayı öncesinde bize etkinlik planından bahsetmeli ki sınıfımıza uygun mu değil mi karar verelim. Çünkü bu süreçte çok pasif hale getiriliyorum. Söz hakkım olmuyor (UÖ2).

Uygulama öğretmenlerinin etkinlik sırasında karşılaştıkları en büyük sorun, öğretmen adayının sınıf yönetimi konusunda zorluk çekmesidir. Bunun nedenleri olarak da çocuklarla iletişim kurmakta zorlanma ve bu konuda deneyim sahibi olmama gösterilmiştir. Uygulama öğretmenlerinin sınıf yönetimini kolaylaştırmak adına önerdikleri çözüm önerisi ise öğretmen adaylarının farklı ve ilgi çekici yöntemler kullanmalarıdır. Katılımcıların verdiği cevaplara ilişkin örnek aşağıda sunulmuştur:

Yeterli deneyime sahip olmadıkları için doğal olarak sınıfı yönetmekte zorlanıyorlar. Bol bol araştırma yapıp dikkat çekici şeyler öğrenmeleri gerek. Mesela kuklalar, bilmeceler, şarkılar, müzik aletleri, tekerlemeler gibi ilgi çekici yöntemler kullansalar işleri kolaylaşabilir. Böylece çocuklar da sıkılmaz ve etkinliğe karşı dikkat süreleri uzar (UÖ6).

Etkinlik sonrasında uygulama öğretmenlerinin karşılaştıkları sorunlar değerlendirme ile ilgilidir. Katılımcılar, öğretmen adayları tarafından öğrenme süreci değerlendirmesinin uygun yapılmadığını ve değerlendirme yapılırken her çocuğa eşit davranılmadığını belirtmişlerdir. Değerlendirme sürecinin tek tip sorularla yapıldığı ve hep aynı çocuklara söz hakkı verildiğini ifade etmişlerdir. Uygulama öğretmenlerinin bu konudaki çözüm önerileri ise değerlendirmenin sorular dışında poster hazırlama, gözlem yapma gibi farklı yöntemlerle de yapılması ile tüm çocukların değerlendirilmesidir.

Etkinlik dışında uygulama öğretmenlerinin en çok üzerinde durdukları sorun, öğretmen adaylarının etkinlik dışında çocuklarla ilgilenmemesidir. Bu durumla ilgili çözüm önerileri ise öğretmen adaylarının her zaman çocukları gözlemlemesinin sağlanması ve iletişim içinde olmalarıdır. Katılımcıların verdiği cevaplara ilişkin örnek aşağıda sunulmuştur:

Öğretmen adaylarımız etkinlik bittikten sonra benim de işim bitti diye düşünüyorlar. Halbuki öyle olmaması lazım, deneyim kazanmaları için her an çocuklarla iletişim halinde olmalılar. Mesela serbest oyun zamanında onlarla oynamalı, oynamıyorsa bile gözlem yapmalı ki mesleğe başladığında bugünleri hatırlayıp öğrendiklerini uygulayabilsinler (UÖ8).

\section{Öğretmenlik Uygulaması Sürecinde Kişilere Düşen Sorumluluklar}

Açık uçlu görüşme formunda katılımcılara Öğretmenlik Uygulaması sürecinde kişilere düşen sorumluluklar ile ilgili sorular sorulmuştur. Tablo 5 'te okul öncesi öğretmen adaylarının ve uygulama öğretmenlerinin konuyla ilgili görüşlerine yer verilmiştir.

\section{Tablo 5}

Sorumluluklar

\begin{tabular}{|c|c|c|c|}
\hline Kişiler & $\begin{array}{l}\text { Uygulama öğrencisi } \\
\text { (öğretmen adayı) }\end{array}$ & Uygulama öğretmeni & Uygulama öğretim elemanı \\
\hline $\begin{array}{l}\text { Sorumluluklar } \\
\text { (Öğretmen Adayı } \\
\text { Bakış Açısı) }\end{array}$ & $\begin{array}{l}\text { Etkinliklerine hazırlıklı gelmek } \\
(\mathrm{n}=37) \\
\text { Çocukları tanıyarak ilgi, ihtiyaç } \\
\text { ve gelişim özelliklerine göre } \\
\text { etkinlik yazmak ( } \mathrm{n}=33) \\
\text { Olumlu kişisel özelliklere sahip } \\
\text { olmak ( } \mathrm{n}=23) \\
\text { Uygulama öğretmeniyle iletişim } \\
\text { halinde olmak }(\mathrm{n}=14)\end{array}$ & $\begin{array}{l}\text { Öğretmen adayıyla iletişim } \\
\text { halinde olarak ona destek olmak, } \\
\text { dönüt vermek }(n=36) \\
\text { Aday öğretmene abla } \\
\text { dedirtmeyip onu gelecekteki } \\
\text { meslektaşı olarak görmek }(n=33) \\
\text { Öğretmen adayına gerekmedikçe } \\
\text { müdahale etmemek }(n=13)\end{array}$ & $\begin{array}{l}\text { Gözlem yaparak öğretmen } \\
\text { adayına dönüt vermek }(n=40) \\
\text { Öğretmen- öğretmen adayı- } \\
\text { üniversite arasında köprü olmak } \\
(n=37) \\
\text { Anlayışlı ve esnek olmak }(n=12)\end{array}$ \\
\hline $\begin{array}{l}\text { Sorumluluklar } \\
\text { (Uygulama Öğgretmeni }\end{array}$ & $\begin{array}{l}\text { Etkinliklerine hazırlıklı gelmek } \\
(\mathrm{n}=26)\end{array}$ & $\begin{array}{l}\text { Öğretmen adayıla iletişim } \\
\text { halinde olarak ona destek olmak, }\end{array}$ & $\begin{array}{l}\text { Gözlem yaparak öğretmen } \\
\text { adayına dönüt vermek }(n=23)\end{array}$ \\
\hline
\end{tabular}




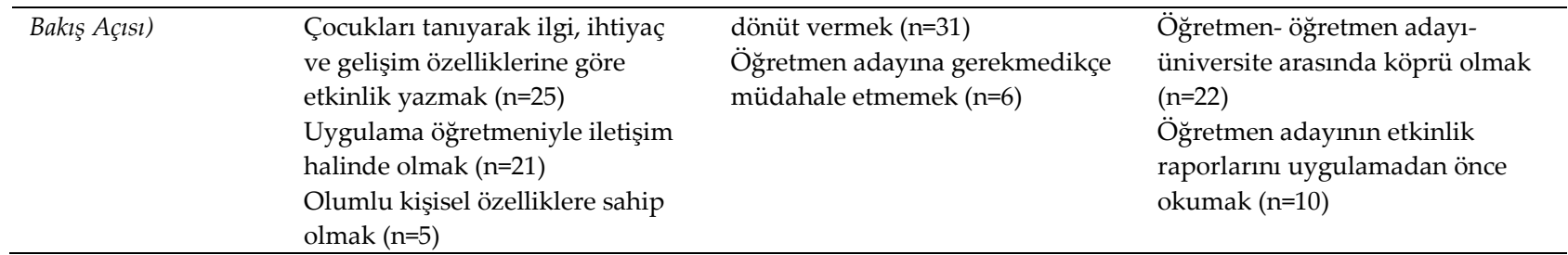

Tablo 5'te görüldüğü üzere katılımcıların açık uçlu görüşme formundaki Öğretmenlik Uygulaması sürecinde kişilere düşen sorumluluklar ile ilgili sorulara verdikleri cevaplar uygulama öğrencisi, uygulama öğretmeni ve uygulama öğretim elemanı olmak üzere üç kategoriye ayrılmıştır.

Uygulama öğrencisine düşen sorumluluklara bakıldığında öğretmen adaylarının ve uygulama öğretmenlerinin görüşlerinin benzerlik gösterdiği görülmektedir. İfade edilen görüşlerin büyük çoğunluğu etkinlik hazırlığı ile alakalıdır. Katılımcılar, uygulama öğrencilerinin uygulama öğretmeniyle iletişimde olarak, çocuklara uygun etkinlikler hazırlamalarını ve etkinliklere hazırlıklı gelmeleri gerektiğini ifade etmişlerdir. Etkinlik hazırlıklarının yanı sıra, uygulama öğrencilerinin güler yüzlü, sevecen, merhametli olma gibi olumlu kişisel özelliklere sahip olması da iki katılımcı grubu tarafından ifade edilen görüşlerdendir. Uygulama öğrencisine düşen sorumluluklarla ilgili bir katılımcının görüşü aşağıda örnek olarak sunulmuştur:

Öğretmen adayı önceden etkinlik planını hazırlamalı. Planın uygun olup olmadığını bana sormalı. Benimle hiç konuşmadan haberim olmayan bir etkinliği uygulamamalı. Sınıfa gelmeden bütün hazırlıklarını tamamlamış olmalı. Yani etkinliğe beş dakika kala kullanacağı bir materyal eksik olmamalı. Ayrıca çocuklara karşı güler yüzlü olma ki çocuklar kendilerini rahat hissedebilsin (UÖ7).

Uygulama öğretmenine düşen sorumluluklara bakıldığında her iki katılımcı grubunun da ortak noktalarda buluştuğu görülmektedir. Uygulama öğretmeninin öğretmen adayıyla iletişim içinde olarak ona destek olması, dönüt vermesi katılımcılar tarafından en çok ifade edilen sorumluluk olurken uygulama öğretmeninin öğretmen adayına gerekmedikçe müdahale etmemesi gerektiği üzerinde de durulmuştur. Bunlara ek olarak, öğretmen adayları uygulama öğretmenlerinin kendilerine "abla" dedirtmemeleri gerektiğini ve onları gelecekteki meslektaşları olarak görmeleri gerektiğini de söylemişlerdir. Konuyla alakalı katılımcların verdiği cevaplara ilişkin örnek aşağıda sunulmuştur:

Daha stajın ilk günü öğretmenlerin bizi abla olarak tanıtmaları bütün staj sürecimizi olumsuz etkiliyor. Bizi meslektaşları olarak görmüyorlar. Onlar bizi öğretmen olarak görmedikleri için çocuklar da otoritemizi sorguluyor. Bu yüzden bence en büyük sorumlulukları bizi Ayşe Abla (gerçek isim kullanılmamıştır) diye tanıtmak yerine Ayşe Öğretmen diye tanitmak (ÖA6).

Uygulama öğretim elemanına düşen sorumluluklara bakıldığında katılımcıların benzer görüşleri savundukları görülmektedir. Uygulama öğretim elemanının öğretmen adayını gözlemlemesi ve ona dönüt vermesi en çok ifade edilen görüşlerden olurken; okul ile üniversite arasında köprü görevini üstlenmesi gerektiği de birçok katılımcı tarafından belirtilmiştir. Bunlara ek olarak, öğretmen adayları uygulama öğretim elemanlarının anlayışlı ve esnek olmaları gerektiğini belirtirken; uygulama öğretmenleri ise öğretmen adaylarının etkinliklerini uygulamadan önce uygulama öğretim elemanının etkinlik raporlarını okuması gerektiğini ifade etmişlerdir. Konuyla alakalı katılımcıların verdiği cevaplara ilişkin örnekler aşağıda sunulmuştur:

Üniversiteden gelen hocalarımızın öğrencilerini belirli aralıklarla gözlemlemesi ve onlara ihtiyaç halinde dönüt vermeleri gerektiğini düşünüyorum. Bazen bizim gözümüzden kaçan şeyler olabiliyor ve gerektiği gibi geri bildirimlerimizi veremiyoruz. Aslında biz ne kadar düşüncelerimizi söylesek de öğretmen adaylarımız hocalarının görüşlerine daha fazla önem veriyorlar (UÖ14).

Bence hocalarımız okul yönetimi ve öğretmenler ile biz öğrenciler arasındaki iletişimi sağlamalı, denge kurmalı ve iki tarafın da ihtiyaçlarına yönelik tutum sergilemeli. Mesela dönem başında okula gidip bizim bütün yapmamız gerekenleri okula da açıklamalılar ki bizden fazlası istenmesin. Bu sayede herkes karşı tarafa olan sorumluluklarını öğrenmiş olur (ÖA3).

Etkinliklere geri dönüt verilirken ya da uygulama sonrası gözlem notları paylaşılırken daha anlayışlı olmaları gerektiğini düşünüyorum. Kullanılan dil gerçekten çok önemli. Bazı dönütler motivasyonumu düşürebiliyor. Sonuçta biz daha mezun olmadık ve bunlar bize tecrübe olacak. Daha motive edici olsalar bize faydalı olur (ÖA21). 


\section{Sonuç ve Tartışma}

Bu çalışmanın amacı okul öncesi öğretmen adaylarının ve uygulama öğretmenlerinin Öğretmenlik Uygulaması dersine ilişkin görüşlerini incelemektir. Okul öncesi öğretmen adaylarının ve uygulama öğretmenlerinin Öğretmenlik Uygulaması sürecinde karşılaştıkları sorunlara, bu sorunlara yönelik çözüm önerilerine ve bu süreçte kişilere düşen sorumluluklara ilişkin görüşleri oldukça önemlidir. Bu nedenle yapılmış olan bu çalışmanın alan yazına katkı sağlayacağı umulmaktadır.

Araştırma sonucunda, okul öncesi öğretmen adaylarının ve uygulama öğretmenlerinin Öğretmenlik Uygulaması sürecinde karşılaştıkları sorunlara ve bu sorunlara yönelik çözüm önerilerine ulaşılmıştır. Katılımcıların görüsslerine göre sınıf düzeninin uygulanacak etkinliğe uygun olmaması bu sorunlardan birisidir. Benzer olarak Karaca ve Aral'ın (2011) çalışmasında da aynı konu üzerinde durulmuştur. Öğretmen adaylarının sınıf düzeni uygun olmadığı için uygulayacakları etkinlikleri değiştirmek zorunda kaldıkları ifade edilmiştir. Devlete bağlı okul öncesi eğitim kurumlarında yer alan sınıflar düşünüldüğünde çoğunun içinde bulunan çocuk sayısına göre küçük olduğu ve çocukların hareketli etkinlikleri için yeterli alana sahip olmadıkları bilinmektedir. Ancak sınıflarda yer alan masa, sandalye ya da öğrenme merkezleri kolaylıkla hareket edebilen, yeri değiştirilebilen mobilyalar ve materyaller olduğundan öğretmen adayları sınıfı etkinliklerine uygun hale getirebilirler. Burada önemli olan noktanın öğretmen adaylarının etkinliklerine başlamadan önce sınıf düzenini uygun hale getirmeleri olduğu düşülmektedir. Buna ek olarak, öğretmen adaylarının sınıf düzeni ile ilgili sınıf öğretmeninden yardım ve gerekli değişiklikleri yapmaları için onay almaları önerilebilir.

Araştırma sonucunda elde edilen bir diğer bulgu ise öğretmen adaylarının materyallere ulaşmada yaşadıkları maddi sıkıntılar ile ilgilidir. İlgili alan yazın incelendiğinde bu bulgu ile paralel bulgular gösteren çalışmalar bulunmaktadır (Aslan ve Sağlam, 2018; Demir ve Çamlı, 2011; Karaca ve Aral, 2011). Bu doğrultuda uygulama okullarının sahip oldukları olanakları, sınıfta var olan materyalleri öğretmen adaylarının kullanımına izin vermeleri önerilebilir. Buna ek olarak, öğretmen adaylarının da hazır materyaller kullanmak yerine kendi materyallerini geliştirmeleri, bunu yaparken de kolay erişebilecekleri kozalak, taş, yaprak gibi doğal materyaller ya da atık materyaller kullanmaları da öneriler arasında yer alabilir. Materyallerle ilgili karşılaşılan maddi sorunlara ek olarak, öğretmen adaylarının yemek gibi temel ihtiyaçlarının uygulama okullarında karşılanmaması da bu çalışma sonucunda elde edilen bulgular arasındadır. Alan yazına bakıldığında Demir ve Çamlı (2011) tarafından yapılan çalışmada da aynı sorunla karşılaşan katılımcıların olduğu görülmektedir. Bu tür bulguların nedeni, okulların özel durumları olabilir. Bulundukları yer ya da velilerden aldıkları destek gibi farklılıklar nedeniyle yalnızca çocuklara ve kendi çalışanlarına yetecek kadar yemek hazırlanması, öğretmen adaylarına yemek verilmemesini açılayabilir.

Araştırma sonucunda öğretmen adayı ve uygulama öğretmeni arasında anlaşmazlıkların yaşanması öğretmen adayları tarafından vurgulanan ve en çok göze çarpan bulgulardan biridir. Öğretmen adayları uygulama öğretmenleri ile sağlıklı iletişim kuramadıkları için uygulanan etkinliklerin beklentileri karşılamadığını, ya da uygulama öğretmenlerinin etkinlik sonrasında dönüt vermediğini sorun olarak gördüklerini ifade etmişlerdir. Ancak uygulama öğretmenleri süreç boyunca karşılaşılan iletişim problemini ya da öğretmen adaylarına vermeleri gereken dönütleri karşılaşılan problemler olarak dile getirmemişlerdir. İlgili alan yazın incelendiğinde bu bulgular ile paralel bulgular gösteren çalışmalar göze çarpmaktadır. Bazı çalışmalarda öğretmen adayı ve uygulama öğretmeni arasında kurulacak olan iletişimin önemi vurgulanırken (Gündoğdu, Coşkun, Albez ve Bay, 2010; Karaca ve Aral, 2011; Köroğlu, Başer ve Güneş, 2000; Oğuz ve Avc1, 2014; Seçer, Çeliköz ve Kayılı, 2010); bazılarında ise uygulama öğretmenlerinin verdikleri dönütlerin öğretmen adaylarının mesleki gelişimi açısından önemli olduğu savunulmuştur (Aslan ve Sağlam, 2018; Değirmençay ve Kasap, 2013; Eraslan, 2009; Özmen, 2008; Paker, 2008; Sarıçoban, 2008). Bu doğrultuda, öğretmen adayı ile uygulama öğretmeni arasında anlaşmazlıkların yaşanmaması için uygulanacak etkinliklerin önceden konuşulması ve uygulama sonrasında uygulama öğretmenlerinin dönütlerini öğretmen adayıyla paylaşarak sürecin daha verimli hale getirilebileceği söylenebilir. Buna ek olarak, uygulama öğretmenlerinin süreç boyunca karşılaştıkları problemler ile kişilerin sahip olduğu sorumluluklar kısmında dile getirdikleri görüşlerin tutarsız olduğu görülmektedir. Yani uygulama öğretmenlerinin öğretmen adayları ile iletişim 
içinde olma ve gerektiğinde onlara dönüt verme sorumluluğu kişilerin sahip olması gereken sorumluluklar kısmında dile getirilirken; karşılaşılan problemler başlığ ${ }_{1}$ altında dile getirilmemiştir. Bu da uygulama öğretmenlerinin sorumluluklarının farkında olduğu ve bu sorumlulukları probleme dönüşmeden yerine getirdiklerini varsaydıklarından olabilir.

Araştırma sonucunda elde edilen bir diğer bulgu ise öğretmen adaylarının sınıf yönetimi ile ilgili yaşadığı sorunlarla ilgilidir. Uygulama öğretmeninin öğretmen adayını sınıfta yalnız bırakması, öğretmen diye tanıtmak yerine abla/abi diyerek tanıtması gibi nedenlerden dolayı öğretmen adayları, sınıfta hakimiyet kurmakta zorlandıklarını ifade etmişlerdir. İlgili alan yazın incelendiğinde bu bulguların farklı çalışmaların bulguları ile desteklendiği görülmektedir (Demir ve Çamlı, 2011; Karaca ve Aral, 2011; Karadüz ve diğerleri, 2009; Karasu Avcı ve Ünal İbret, 2016). Bu doğrultuda eğitimlerinin son yılına gelen öğretmen adaylarının sınıf yönetiminde zorluk çekmelerinin nedeni, bugüne kadar uygulamaya yönelik derslerinin yeterli gelmemesi olabilir. Buna ek olarak, sınıf yönetimi alan yazınına bakıldığında sınıfta bireyler arası sağlanan olumlu ilişki, öğretmenin sözel olmayan davranışları, çocukların davranışlarının düzenlenmesi, sınıfta uyulması gereken kuralların belirlenmesi, zaman yönetimi ve iletişim gibi becerilerin de sinıf yönetimini sağlamada kritik bir öneme sahip olduğu söylenmektedir (Akgün, Yarar ve Dinçer, 2011; Bulut, 2008; Celep, 2004; Ekici, 2004; Erden, 2005; Şeker, 2000). Ancak yukarıda bahsi geçen sinıf yönetimi becerilerinin öğretmenlik tecrübesi ile doğru orantılı olarak geliştiği de alan yazındaki çalışmaların bulguları arasında göze çarpmaktadır (Dinçer ve Akgün, 2015; O’Brien ve Goddard, 2006; Yeşilyurt ve Çankaya, 2008). Bu nedenle, eğitim fakültelerinde son yıl haftada sadece bir gün olarak düzenlenen Öğretmenlik Uygulaması dersinin uygulamaya dönük kısmının özellikle son dönem, haftada iki güne çıkarılması önerilebilir. Öğretmenlik Uygulaması dersine ek olarak, öğretmen adaylarının sorumlu olduğu diğer derslerin uygulama boyutunun arttırılması da öneri olarak sunulabilir. Bu sayede, öğretmen adayları mesleğe başlamadan önce daha fazla öğretmenlik deneyimine sahip olma şansı elde etmiş olurlar.

Öğretmenlik Uygulaması sürecinde kişilere düşen sorumluluklar ile ilgili bulgulara bakıldığında kişiler arası iletişimin sağlıklı bir şekilde yürütülmesi gerektiği öne çıkan bulgulardandır. Bu bulgulara paralel olarak alan yazında da öğretmen adayı, uygulama öğretmeni ve uygulama öğretim elemanı arasındaki iletişimin önemi sıkça vurgulanmaktadır (Gündoğdu ve diğerleri, 2010; Karaca ve Aral, 2011; Seçer ve diğerleri, 2010). Hatta bu iletişimde uygulama öğretim elemanının fakülte- okul iş birliğini sağlayarak köprü görevi gördüğü de hem yapılan bu çalışmada hem de alan yazında belirtilmiştir (Akpınar ve diğerleri, 2012; Baştürk, 2007; Paker, 2008; Sağ, 2008; Sılay ve Gök, 2004; Yapıcı ve Yapıcı, 2004; Yıldız Altan ve diğerleri, 2018). Uygulama öğretim elemanlarının fakülte- okul iş birliğini sağlamasına ek olarak öğretmen adayına dönüt vermesi sorumluluğu da bulgular arasındadır. Alan yazında yer alan farklı çalışmaların bulguları bunu destekler niteliktedir (Aslan ve Sağlam, 2018; Şimşek ve diğerleri, 2013; Yeşilyurt ve Semerci, 2011). Bu bulgular ışı̆̆ında çalışmaya katılan öğretmen adaylarının ve uygulama öğretmenlerinin, uygulama öğretim elemanlarının sorumlulukları konusunda farkındalık sahibi olduğunu söylemek mümkündür. Aslında Milli Eğitim Bakanlığı (MEB) tarafından 2018 yılında yayınlanan Öğretmenlik Uygulamasına ilişkin yönergede, uygulama öğrencileri ve öğretmenlerinin görev ve sorumluluklarına ek olarak uygulama öğretim elemanlarının görev ve sorumlulukları da açıkça belirtilmiştir. Bu yönergeye göre uygulama öğretim elemanı, uygulama öğrencisinin etkinlik planlamasında etkin rol oynamalı, uygulama öğrencisine rehberlik, danışmanlık yapmalı, uygulama öğrencisinin devam-devamsızlık takibini yapmalı, her dönemde en az dört kez uygulama öğrencisinin dersine fiilen katılmalı, uygulama öğrencisine dönüt vermeli ve uygulama sonunda sorumlu olduğu öğrencinin değerlendirmesini yapmalıdır (MEB, 2018). Öğretmenlik Uygulaması sürecinde önemli rol oynayan bütün paydaşların görev ve sorumluluklarının ilgili yönergede açıkça belirtildiği görülmüştür. Ancak çalışma bulgularında hala bunlarla ilgili sorunların yaşandığı görülmektedir. Bu bulgulardan yola çıkarak yazılı olarak var olan ve herkes tarafından bilinen kişilere düşen görev ve sorumlulukların uygulamaya dönüşme aşamasında aksaklıklara uğradığı söylenebilir. Buna ek olarak, bu tür sorunların yaşanmaması ve uygulamanın da alınan kararlara göre gerçekleşmesi için denetimlere gerek duyulmadan bütün paydaşların sorumluluklarının farkında olup gereğini yerine getirmeleri önerilebilir. Ayrıca süreçte en az öğretmenler ve öğretmen adayları kadar aktif rol alan öğretim elemanlarının da çalışmada katılımcı olarak yer almaları ve görüşlerini paylaşmaları ile uygulama sürecinin daha verimli ve etkili olabilmesi için 
uygulama öğretim elemanının öğretmen adaylarına ve gerektiğinde öğretmenlere sağlayacağı danışmalığın niteliğini etkileyen faktörlerin araştırılması ve bu niteliğin arttırılması yönünde çalışmaların yapılması önerilebilir.

Sonuç olarak bu çalışma, alan yazına üç farklı konuda katkıda bulunabilir. İlk olarak katılımcılar arasında öğretmen adayları olduğu için Öğretmenlik Uygulaması sürecini onların bakış açısından görmeyi sağlar. Bu sayede yaşanılan problemler deneyimleyen kişiler tarafından ilgili kurumlara ve kişilere iletilmiş olur. İkinci olarak katılımcılar arasında uygulama öğretmenleri olduğu için Öğretmenlik Uygulaması sürecini onların gözüyle görmeye olanak sağlar. Süreç boyunca öğretmen adaylarıyla sınıf içinde en çok zaman geçiren kişiler uygulama öğretmenleri olduğu için onların görüşleriyle süreçten alınacak verim arttırılabilir. Son olarak, bütün katılımcıların dile getirdiği sorunlar ve çözüm önerileri ile Öğretmenlik Uygulaması süreci bütün paydaşlar için etkili ve faydalı hale getirilebilir.

Bu araştırmadan elde edilen bulgular bir bütün olarak değerlendirildiğinde hizmet öncesi eğitimin önemli bir boyutu olan Öğretmenlik Uygulaması dersini daha verimli hale getirmek için okuyuculara bazı öneriler sunulmuştur:

- Öğretmen adayları süreç boyunca sınıf düzeni ile ilgili herhangi bir sorunla karşılaşmamak için etkinliklerini uygulamadan önce sınıfı etkinliklerine uygun hale getirmeli, gerektiğinde öğrenme merkezlerinde veya mobilya yerleşiminde değişiklikler yapmalı ve bu aşamada da uygulama öğretmenlerinden destek almalıdır.

- Okul yönetimi materyal desteği ve yemek molası gibi konularda öğretmen adaylarının yanında olmalıdır. Öğretmen adaylarının temel ihtiyaçlarının karşılanması için üniversitelerin ve okulların bağlı oldukları YÖK ve MEB arasında bir anlaşma yapılmalı, bu anlaşma içeriği ile tüm uygulama okullarında bütün öğretmen adaylarına standart şartlar sunulmalıdır.

- Öğretmenlik Uygulaması sürecinin paydaşları olan öğretmen adayı, uygulama öğretmeni ve uygulama öğretim elemanı arasında anlaşmazlıkların yaşanmaması için etkili iletişim sağlanmalıdır.

- Öğretmen adayları süreç boyunca verilen dönütleri önemsemeli, etkinliklerine hazırlıklı gitmeli ve kendini sınıf yönetimi konusunda geliştirmek için farklı yöntemler öğrenmelidir.

- Uygulama öğretmeni etkinlik planlaması, sınıf yönetimi ve değerlendirme gibi konularda öğretmen adayına model olarak gerektiği yerde dönüt vermelidir.

- Öğretmenlik Uygulaması sürecinde ilgili kişiler sorumluluklarının farkında olmalı ve bu sorumlulukları süreç boyunca yerine getirmelidir.

Bütün araştırmalarda olduğu gibi bu çalışma da özellikle yönteme yönelik sınırlılıklara sahiptir. Bu çalışmanın verileri araştırmacılar tarafından oluşturulan açık uçlu görüş bildirim formu aracılığıyla toplanmıştır. Tek veri toplama aracı bu form olduğu için öğretmenlerin ve öğretmen adaylarının verdiği cevaplar bulguları sınırlandırmıştır. Bu çalışmadan sonra yapılacak olan bilimsel çalışmalarda bulguları zenginleştirmek adına farklı veri toplama araçlarının kullanılması önerilmektedir. Örneğin öğretmen adaylarının uygulamalarının da veri olarak kullanılması için ders planları incelenip etkinlikleri gözlemlenebilir. Araştırmanın sınırlılıklarından bir diğeri ise katılımcılarla ilgilidir. Bu çalışmada Öğretmenlik Uygulaması sürecinde aktif rol alan öğretmen adayları ve uygulama öğretmenlerinin görüşlerine yer verilmiştir. Ancak en az onlar kadar kritik rol oynayan uygulama öğretim elemanları da bundan sonra yapılacak olan çalışmalara katılımcı olarak eklenmelidir.

\section{Yazarların Beyanı}

Araştırmacıların katkı oranı beyanı: Araştırmacılardan Funda Eda Tonga, literatür taraması, veri toplanması ve analizi, giriş, yöntem, bulgular ve tartışmanın yazılmasına; Feyza Tantekin Erden ise, giriş, yöntem, bulgular ve tartışmanın yazılmasına, son okumanın ve dil düzeltmelerinin yapılmasına katkı sağlamıştır.

Etik Kurul Kararı: “Okul Öncesi Öğretmen Adaylarının ve Uygulama Öğretmenlerinin Öğretmenlik Uygulaması Dersine İlişkin Görüşlerinin İncelenmesi" başlıklı araştırma ODTÜ İnsan Araştırmaları Etik 
Kurulu tarafından uygun görülmüş ve 136 ODTU 2020 protokol numarası ile onaylanmıştır.

Çatışma beyanı: Araştırmada, yazarların kendi içinde ve diğer kişi/kurum/kuruluşlarla herhangi bir çıkar çatışması söz konusu değildir.

Destek ve teşekkür: $\mathrm{Bu}$ araştırmanın yürütülmesinde herhangi bir kurum ya da kuruluştan destek alınmamıştır.

\section{Kaynaklar}

Akgün, E., Yarar, M. ve Dinçer, Ç. (2011). The evaluation of class management strategies of preschool teachers in classroom activities. Pegem Eğitim ve Öğretim Dergisi, 1(3), 1-9. doi: 10.14527/c1s3m1

Akpınar, M., Çolak, K. ve Yiğit, E. Ö. (2012). Öğretmenlik uygulaması dersi kapsamında sosyal bilgiler öğretmen adaylarının yeterliklerine yönelik uygulama öğretmenlerinin görüşleri. M. Ü. Atatürk Eğitim Fakültesi Ĕ̆itim Bilimleri Dergisi, 36(36), 41-67.

Aslan, M. ve Sağlam, M. (2018). Öğretmenlik uygulaması dersinin öğretmen adaylarının görüşlerine göre değerlendirilmesi. Hacettepe Üniversitesi Ĕ̆itim Fakültesi Dergisi, 33(1),144-162.

Autry, M. M., Lee, J. ve Fox, J. (2009). Developing a data-driven assessment for early childhood candidates. Journal of Early Childhood Teacher Education, 30(2), 138-149.

Aytaçl1, B. (2012). Ilköğretim matematik öğretmenliği lisans programında yer alan okul deneyimi ve öğretmenlik uygulaması derslerinin değerlendirilmesi (Yayınlanmamış yüksek lisans tezi). Ege Üniversitesi, Sosyal Bilimler Enstitüsü, İzmir.

Azar, A. (2003). Okul deneyimi ve öğretmenlik uygulaması derslerine ilişkin görüşlerin yansımaları. Milli Ĕ̆itim Dergisi, 159, 181-194.

Barnes, R. (2010). Cooperating teacher effectiveness as perceived by student teachers and cooperating teachers in Ohio agricultural education (Yayınlanmamış doktora tezi). Ohio State University, ABD.

Baştürk, S. (2007, Eylül). Öğretmen adaylarının öğretmenlik uygulaması dersiyle ilgili deneyimleri. 16. Ulusal Eğitim Bilimleri Kongresi, Gaziosmanpaşa Eğitim Fakültesi, Tokat.

Bates, A. J. ve Burbank, M. D. (2008). Effective student teacher supervision in the era of no child left behind. The Professional Educator, 32(2), 18-28.

Becit, G., Kurt, A. A. ve Kabakçı, I. (2009). Bilgisayar öğretmen adaylarının okul uygulama derslerinin yararlarına ilişkin görüşleri. Anadolu Üniversitesi Sosyal Bilimler Dergisi, 9(1), 169-184.

Boz, N. ve Boz, Y. (2006). Do prospective teachers get enough experience in school placements? Journal of Education for Teaching, 32(4), 353-368.

Bulut, S. (2008). Okul öncesi sınıflarında zaman yönetimi. Y. Aktaş Arnas ve F. Sadık (Ed.), Okul öncesi eğitimde sını yönetimi (s.103-123) içinde. Ankara: Kök Yayıncllık.

Celep, C. (2004). Sinıf yönetimi ve disiplini (3. bs.). Ankara: Anı Yayıncılık.

Çetintaş, B. ve Genç, A. 2005. Almanca öğretmen adaylarının öğretmenlik uygulaması derslerine ilişkin görüş ve deneyimleri. Hacettepe Üniversitesi Ĕ̆itim Fakültesi Dergisi, 29(29), 75-84.

Davran, E. (2006). Illköğretim kurumlarındaki öğretmenlik uygulamasının öğretmen adaylarının öğretmenlik yeterliliklerini kazanmaları üzerindeki etkisi (Yayınlanmamış yüksek lisans tezi). Yüzüncü Yıl Üniversitesi, Van.

Değirmençay, Ş. ve Kasap, G. (2013). Okul deneyimi ve öğretmenlik uygulaması derslerine ilişkin öğretmen adaylarının görüşleri. Ĕ̆itim Bilimleri Dergisi, 4(2), 47-57.

Demir, Ö. ve Çamlı, Ö. (2011). Öğretmenlik uygulaması dersinde uygulama okullarında karşılaşılan 
sorunların sınıf ve okul öncesi öğretmenliği öğrenci görüşleri çerçevesinde incelenmesi: Nitel bir çalışma. Uludă̆ Üniversitesi Ĕ̆itim Fakültesi Dergisi, 24(1), 117-139.

Dinçer, Ç. ve Akgün, E. (2015). Developing a classroom management skills inventory for preschool teachers and the correlation of preschool teachers' classroom management skills with different variables. Eğitim ve Bilim, 40(177), 187-201. doi: 10.15390/eb.2015.2346

Dursun, Ö. Ö. ve Kuzu, A. (2008). Öğretmenlik uygulaması dersinde yaşanan sorunlara yönelik öğretmen adayı ve öğretim elemanı görüşleri. Selçuk Üniversitesi Ahmet Keleşoğlu Eğitim Fakültesi Dergisi, 25, 159178.

Ekici, G. (2004). Öğretim yönetimi. E. Karip (Ed.), Sınıf yönetimi (s.71-112) içinde. Ankara: Pegem Akademi Yayıncilık.

Eraslan, A. (2009). İlköğretim matematik öğretmen adaylarının 'Öğretmenlik Uygulaması' üzerine görüşleri. Elektronik Fen ve Matematik Ĕ̆itimi Dergisi (EFMED), 3(1), 207-221.

Erden, M. (2005). Sinıf yönetimi. İstanbul: Epsilon Yayıncılık.

Glatter, R., Castle, F., Cooper, D., Evans, J. ve Woods, P. (2005). What's new? Identifying innovation arising from school collaboration initiatives. Educational Management, Administration and Leadership, 33(4), 381-399.

Gökçe, E. ve Demirhan, C. (2005). Öğretmen adaylarının ve ilköğretim okullarında görev yapan uygulama öğretmenlerinin öğretmenlik uygulaması etkinliklerine ilişkin görüşleri. Ankara Üniversitesi Eğitim Bilimleri Fakültesi Dergisi, 38(1), 43-71.

Göktaş, Ö. ve Şad, S. N. (2014). Okul deneyimi ve öğretmenlik uygulaması dersi uygulama öğretmenlerinin seçim süreci: ölçütler, sorunlar ve öneriler. Hacettepe Üniversitesi Ĕ̆itim Fakültesi Dergisi, 29(4), 115-128.

Gündoğdu, K., Coşkun, Z. S., Albez, C. ve Bay, E. (2010). Sınıf öğretmeni adaylarının öğretmenlik uygulamasına ilişkin görüşleri ve beklentileri. Bayburt Üniversitesi Eğitim Fakültesi Dergisi, 5(1), 55-67.

Güzel, H. ve Cerit, N. (2006, Eylül). Tezsiz yüksek lisans alan öğretmenliği öğrencilerinin okul deneyimi etkinliklerinin karşılaştırılması. VII. Ulusal Fen Bilimleri ve Matematik Eğitimi Kongresi. Gazi Eğitim Fakültesi, Ankara.

Güzel, H. ve Oral, I. (2006, Eylül). S.U. Eğitim fakültesi OFMAE bolumu öğrencilerinin okul deneyimi üzerine bir araştırma. VII. Ulusal Fen Bilimleri ve Matematik Eğitimi Kongresi. Gazi Eğitim Fakültesi, Ankara.

Hergüner, G., Arslan, S. ve Dündar, H. (2002). Beden eğitimi ve spor öğretmenliği bölümü öğrencilerinin okul deneyimi dersini algılama düzeyleri. Pamukkale Üniversitesi Ĕ̆itim Fakültesi Dergisi, 1(11), 44-58.

Işıkoğlu, N., İvrendi, A. ve Şahin, A. (2007). Öğretmenlik uygulaması sürecine öğretmen adaylarının gözüyle derinlemesine bir bakış. Eurasian Journal of Educational Research, 26, 131-142.

Karaca, N. H. ve Aral, N. (2011, Nisan). Okul öncesi öğretmen adaylarının öğretmenlik uygulamalarında karşılaştıkları sorunlar. 2nd International Conference on New Trends in Education and Their Implications, Antalya, Türkiye.

Karadüz, A., Eser, Y., Şahin, C. ve İlbay A. B. (2009). Eğitim fakültesi son sınıf öğrencilerinin görüşlerine göre öğretmenlik uygulaması dersinin etkililik düzeyi. Mustafa Kemal Üniversitesi Sosyal Bilimler Enstitüsü Dergisi, 6(11), 442-455.

Karasu Avc1, E. ve Ünal İbret, B. (2016). Öğretmenlik Uygulaması-II dersine ilişkin okul öncesi öğretmen adaylarının görüşlerinin değerlendirilmesi. Kastamonu Eğitim Dergisi, 24(5), 2519-2536.

Kayange, J. J. ve Msiska, M. (2016). Teacher education in China: Training teachers for the 21st century. The Online Journal of New Horizons in Education, 6(4), 204-210.

Köroğlu, H., Başer, N. ve Güneş, Y. (2000). Okullarda uygulama çalışmalarının değerlendirilmesi. Hacettepe Üniversitesi Eğitim Fakültesi Dergisi, 19, 85-95. 
Miles, M. B. ve Huberman, A. M. (1994). Qualitative data analysis: An expanded source book (2. bs.) United States of America: Sage Publication.

Milli Eğitim Bakanlığı. (2018). Uygulama öğrencilerinin Milli Eğitim Bakanlığına bağlı eğitim öğretim kurumlarında yapacakları Öğretmenlik Uygulamasına ilişkin yönerge. Milli Eğitim Bakanlı̆̆ı Tebliğler Dergisi, 81(2729), 1-48.

O'Brien, P. ve Goddart, R. (2006). Beginning teachers: Easing the transition to the classroom. The Australian Educational Leader, 28(1) 28-31.

Oğuz, S. ve Avcı, E. (2014). Sosyal Bilgiler öğretmen adaylarının okul deneyimi dersine yönelik görüşleri. Cumhuriyet International Journal of Education, 3(3), 40-53.

Özay Köse, E. (2015). Okul deneyimi ve öğretmenlik uygulaması derslerine yönelik öğrenci ve öğretmenöğretim elemanı tutumları (Erzurum örneği). Dicle Üniversitesi Ziya Gökalp Eğitim Fakültesi Dergisi, 22, 117.

Özkılıç, R., Bilgin, A. ve Kartal, H. (2008). Öğretmenlik uygulaması dersinin öğretmen adaylarının görüşlerine göre değerlendirilmesi. İlköğretim Online, 7(3), 726-737.

Özmen, H. (2008). Okul deneyimi I ve okul deneyimi II derslerine ilişkin öğretmen adaylarının görüşleri. Ondokuz Mayıs Üniversitesi Ĕ̆itim Fakültesi Dergisi, 25, 25-37.

Paker, T. (2008). Öğretmenlik uygulamasında öğretmen adaylarının uygulama öğretmeni ve uygulama öğretim elemanının yönlendirmesiyle ilgili karşılaştıkları sorunlar. Pamukkale Üniversitesi Eğitim Fakültesi Dergisi, 23(1), 132-139.

Pitfielda, M. ve Morrison (2009). Teachers' experiences of mentoring on a flexible initial teacher education programme: Implications for partnership development. Journal of Education for Teaching, 35(1), 19-32.

Poulou, M. (2007). Personal teaching efficacy and its sources: Student teachers' perceptions. Educational Psychology, 27(2), 191-218. doi:10.1080/01443410601066693

Sağ, R. (2008). Öğretmen adaylarının uygulama öğretmenlerinden, uygulama öğretim elamanlarından ve uygulama okullarından beklentileri. Eurasian Journal of Educational Research, 32, 117-132.

Saracho, O. N. ve Spodek, B. (2007). Early childhood teachers' preparation and the quality of program outcomes. Early Child Development \& Care, 177(1), 71-91.

Sarıçoban, A. (2008). Okul deneyimi ve öğretmenlik uygulaması derslerine ilişkin uygulama öğretmenleri ve öğretmen adaylarının görüşleri. Gazi Üniversitesi Gazi Eğitim Fakültesi Dergisi, 28(3), 31-55.

Seçer, Z., Çeliköz, N. ve Kayılı, G. (2010). Okul öncesi öğretmenliği okul uygulamalarında yaşanan sorunlar ve çözüm önerileri. Yüzüncü Yıl Üniversitesi, Eğitim Fakültesi Dergisi, 7(1), 128-152.

Segall, W. E. ve Wilson, A. V. (2004). Introduction to education: Teaching in a diverse society. Maryland: Rowman \& Littlefield.

Severcan, S. (2007). Okul öncesi öğretmen adaylarının uygulama yaptıkları okul öncesi eğitim kurumlarında karşılaştıkları sorunların belirlenmesi (Yayımlanmamış yüksek lisans tezi). Hacettepe Üniversitesi, Sosyal Bilimler Enstitüsü, Ankara.

Sılay, İ. ve Gök, T. (2004, Temmuz). Öğretmen adaylarının uygulama okullarında karşılaştıkları sorunlar ve bu sorunları gidermek amacıyla hazırlanan öneriler üzerine bir çalışma. XIII. Ulusal Eğitim Bilimleri Kurultayı, İnönü Üniversitesi Eğitim Fakültesi, Malatya.

Şeker, A. (2000). Sınfföğretmenlerinin iletişim becerileri ile sını atmosferi arasındaki iliş̧kinin çeşitli değişkenler açısından incelenmesi (Yayımlanmamış yüksek lisans tezi). Selçuk Üniversitesi, Konya.

Şimşek, S., Alkan, V. ve Erdem, A. R. (2013). Öğretmenlik uygulamasına ilişkin nitel bir çalışma. Pamukkale Üniversitesi Ĕ̆itim Fakültesi Dergisi, 34, 63-73. 
Wagler, R. R. (2007). Assessing the impact of vicarious experiences on preservice elementary science teacher efficacy and preservice elementary teacher efficacy (Yayımlanmamış doktora tezi). Oklohama State University, Oklahoma.

Yalın Uçar, M. (2012). Öğretmenlik uygulamasına ilişkin durum çalışması. Kuram ve Uygulamada Eğitim Bilimleri, 12(4), 2637-2660.

Yapıcı, Ş. ve Yapıcı, M. (2004). Öğretmen adaylarının Okul Deneyimi I dersine ilişkin görüssleri. İlköğretim Online, 3(2), 54-59.

Yeşilyurt, E. ve Çankaya, İ. (2008). Sınıf yönetimi açısından öğretmen niteliklerinin belirlenmesi. Elektronik Sosyal Bilimler Dergisi, 7(23), 274-295.

Yeşilyurt, E. ve Semerci, Ç. (2011). Uygulama öğretmenlerinin öğretmenlik uygulaması sürecinde karşılaştıkları sorunlar ve çözüm önerileri. Akademik Bakış Dergisi, 27, 1-23.

Yıldırım R. G., Özyılmaz Akamca G., Ellez A. M., Karabekmez S. ve Bulut Üner A.N. (2019). Okul öncesi öğretmen adaylarının okul deneyimi ve öğretmenlik uygulaması derslerine ilişkin görüşlerinin incelenmesi. Yükseköğretim ve Bilim Dergisi/Journal of Higher Education and Science, 9(2), 306-316. doi:10.5961/jhes.2019.332

Yıldırım, A. ve Şimşek, H. (2011). Sosyal bilimlerde nitel araştırma yöntemleri (8. bs.). Ankara: Seçkin Yayıncılık.

Yıldız Altan, R., Ulutaş, İ. ve Demiriz, S. (2018). Okul öncesi öğretmenliği lisans programında yer alan "öğretmenlik uygulaması" dersine ilişkin görüşlerin karşılaştırılması. Gazi Üniversitesi Gazi Eğitim Fakültesi Dergisi, 38(3), 869-886.

Yükseköğretim Kurulu. (1998). Ĕ̆itim fakültesi öğretmen yetiştirme lisans programları. Ankara: Yükseköğretim Kurulu Yayınları. 


\section{EXTENDED ABSTRACT}

\section{Introduction}

The quality of education depends on teacher qualifications (Kayange \& Msiska, 2016), and pre-service teacher training plays a critical role in enhancing the qualifications of teachers (Saracho \& Spodek, 2007). In the teacher training process, the teaching practice course is one of the most significant classes because it enables pre-service teachers to transfer their theoretical knowledge to real life (YÖK, 1998). Furthermore, this course provides several opportunities to pre-service teachers before they graduate from the university, including observing children from different age groups, preparing lesson plans, developing materials, and assessing children's learning (Demir \& Çaml, 2011). Various studies on the "Practice Teaching" coursework have been conducted, but the literature has mainly focused on the views of pre-service teachers regarding the teaching practice, difficulties encountered during the process, and benefits of the teaching practice (Aslan \& Sağlam, 2018; Göktaş \& Şad, 2014; Paker, 2008). The main purpose of this study is to examine the views of pre-service and in-service early childhood teachers regarding the "Practice Teaching" course.

\section{Method}

This research was designed as a phenomenological study and employed qualitative research methods. The participants of this study included 41 pre-service early childhood teachers who enrolled at a state university in Ankara and 31 in-service early childhood teachers who were working in public schools in Ankara. The data was collected through an open-ended feedback form. There were some questions related to problems and solutions to these problems during the teaching practice process as well as the responsibilities of those involved during this process. Before starting data collection, the researchers secured the necessary permissions from the ethical committee of the university, and all of the participants joined the study voluntarily. The collected data was evaluated using content analysis (Yıldırım \& Şimşek, 2011). After the analysis, codes and categories were presented with the help of tables to facilitate comprehensibility.

\section{Results}

The results were divided into two parts: problems encountered during the process of "Practice Teaching" along with the solutions to these problems and the responsibilities of those actively involved in the practice teaching process. In the first part, the participants' views were categorized as before, during, after the activity, and out of the activity time. According to participants, they encountered several problems during the "Practice Teaching" process, such as: difficulties in classroom arrangement and management; economic issues related to materials; lack of communication between pre-service and in-service teachers; inappropriate activities for children's interests, needs, and developmental levels; insufficient assessment of the activities; teacher interruption; and lack of feedback. They also mentioned appropriate solutions for these problems, like arranging classroom before the activity, learning interesting methods to enhance classroom management skills, providing materials to pre-service teachers to take away their economic concerns, and supplying feedback for pre-service teachers. In the second part, the responsibilities of people who are active in the "Practice Teaching" process were categorized as the responsibilities of pre-service teachers, in-service teachers, and professors. According to participants, pre-service teachers need to be prepared for the activity, to have positive personality traits, to try to establish good communication with the classroom teacher, and to be careful about children's interests, needs and developmental levels. Furthermore, in-service teachers need to communicate with the candidate teacher, support his/her in every aspect, give feedback related to applied activities, and not interrupt before the activity finished. Last, professors need to observe the candidate teacher during the activity process, give feedback after the activity, and play a role as a bridge between the practice school and the university in the whole process.

\section{Conclusion}

Based on the findings of the study, the process of practice teaching can be seen from the perspectives of both pre-service and in-service teachers, who are the most active individuals in this process. By doing so, the problems encountered in practice teaching could be conveyed to the related individuals firsthand, and the 
effectiveness of practice teaching could be increased. There were some recommendations to make the "Practice Teaching" better, listed here.

- The classroom needs to be arranged according to the requirements of the activities before applying them by pre-service teachers and in-service teachers need to support pre-service teachers regarding classroom arrangement.

- The school administration needs to support pre-service teachers in economic issues, like securing the necessary materials for instructional activities.

- Individuals need to establish a bond between themselves to communicate well.

- Pre-service teachers need to consider all feedback, prepare appropriate activities, and learn different methods to enhance their classroom management skills.

- In-service teachers need to be role models and give feedback to pre-service teachers concerning the activity planning, classroom management, and assessment.

- Individuals who play active role in Practice Teaching process need to be aware of their responsibilities and fulfill these responsibilities throughout the process.

The current study had some limitations especially related to method. The first limitation is about data collection instrument. In this study, the researchers utilized open-ended feedback form in order to collect views of the participants. For further research, various data collection instruments are recommended to collect detailed data such as lesson plan documents of the participants. Secondly, participants of the study can be seen as a limitation because only pre-service and in-service early childhood teachers attended to the study. However, professors play critical role on the process of Practice Teaching. For further research, researchers can collect data from professors in order to enrich the study. 